\title{
Recursos de informática na terapia fonoaudiológica de crianças do espectro autístico*****
}

\author{
Computerized resources in language therapy with children of the \\ autistic spectrum
}

\author{
Fernanda Dreux Miranda Fernandes* \\ Thaís Helena Ferreira Santos** \\ Cibelle Albuquerque de la Higuera Amato*** \\ Daniela Regina Molini-Avejonas****
}

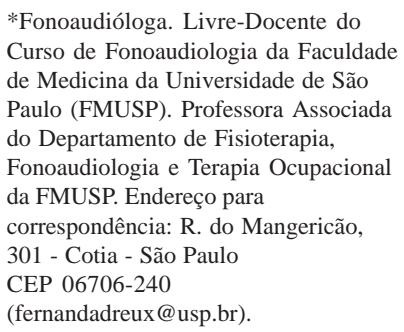

*Fonoaudióloga. Livre-Docente do Curso de Fonoaudiologia da Faculdade de Medicina da Universidade de São Paulo (FMUSP). Professora Associada do Departamento de Fisioterapia, Fonoaudiologia e Terapia Ocupacional da FMUSP. Endereço para correspondência: R. do Mangericão, 301 - Cotia - São Paulo

CEP 06706-240

(fernandadreux@usp.br).

**Fonoaudióloga. Mestranda em Ciências da Reabilitação pela FMUSP

***Fonoaudióloga. Doutora em Linguística pela Universidade de São Paulo. Fonoaudióloga do Departamento de Fisioterapia, Fonoaudiologia e Terapia Ocupacional da FMUSP.

****Fonoaudióloga. Doutora em Ciências pela FMUSP. Professora Doutora do Departamento de Fisioterapia, Fonoaudiologia e Terapia Ocupacional da FMUSP.

*****Trabalho Realizado no Laboratório de Investigação Fonoaudiológica nos Distúrbios do Espectro Autístico do Departamento de Fisioterapia, Fonoaudiologia e Terapia Ocupacional da FMUSP.

Artigo Original de Pesquisa

Artigo Submetido a Avaliação por Pares

Conflito de Interesse: não

\begin{abstract}
Background: the use of computerized technology in language therapy with children of the autistic spectrum. Aim: to assess the interference of using computers and specific programs during language therapy in the functional communicative profile and socio-cognitive performance of children of the autistic spectrum. Method: 23 children with ages ranging between 3 and 12 years were individually video recorded prior to and after a set of 10 regular language therapy sessions (i.e. a total of two video samples per subject) using computerized games according to the child's choice. Results: the following expressions were used by the therapists to describe the children's performance during the use of computers: more attentive, more communicative initiatives, more eye contact, more interactive, more verbalizations, more attention and more action requests. Qualitative and quantitative progresses were identified, although without statistical significance. Those progresses were observed after a time period that is smaller than the usually applied to this kind of comparison and it seems to be a promising result. Conclusion: more controlled associations and comparisons were not possible due to the groups' heterogeneity and therefore more consistent conclusions are not possible. It was clear that the subjects presented different reactions to the use of computerized resources during language therapy.
\end{abstract}

Key Words: Autistic Disorder; Language Therapy; Language; Child.

\section{Resumo}

Tema: uso da tecnologia de informática na terapia de linguagem com crianças do espectro autístico. Objetivo: verificar a interferência do uso de computadores e programas específicos na terapia fonoaudiológica de crianças autistas em seu perfil comunicativo e desempenho sócio-cognitivo. Método: 23 crianças entre 3 e 12 anos foram filmadas individualmente, antes e depois de um bloco de dez sessões com o uso de jogos de informática, em situações regulares de terapia fonoaudiológica, brincando com diversos tipos de jogos, à sua escolha, com a terapeuta, totalizando duas filmagens de cada criança. Resultados: as seguintes características foram descritas pelas terapeutas para as situações com o uso do computador: mais atento, mais iniciativas de comunicação, mais contato ocular, mais interativo, mais verbalizações, mais pedidos de informação e de ação. Foi possível identificar progressos qualitativos e quantitativos, embora sem significância estatística. Esses progressos foram observados num período de tempo mais curto do que o usualmente utilizado para esse tipo de comparação, e esse parece um resultado promissor. Conclusão: não foi possível realizar comparações ou associações mais controladas, pois os grupos estudados foram muito heterogêneos, o que dificulta conclusões mais consistentes. Ficou evidente que os sujeitos apresentaram reações diferentes à proposta de utilização dos recursos de informática durante a terapia fonoaudiológica.

Palavras-Chave: Transtorno Autístico; Fonoaudiologia; Linguagem; Criança.

Recebido em 01.06.2010.

Revisado em 13.07.2010; 19.07.2010; 20.07.2010; 27.08.2010; 01.09.2010; 07.10.2010.

Aceito para Publicação em 30.11.2010.

Referenciar este material como:

Fernandes FDM, Santos THF, Amato CAH, Molini-Avejonas DR. Computerized resources in language therapy with children of the autistic spectrum (original title: Recursos de informática na terapia fonoaudiológica de crianças do espectro autístico). Pró-Fono Revista de Atualização Científica. 2010 out-dez;22(4):415-20. 


\section{Introduction}

Language's role within the autism spectrum disorders is very unique because unlike other broad developmental disorders, where language impairments are a symptom or a consequence of other deficits, in the autism spectrum the language impairments are one of the 3 diagnostic criteria 1 .

The implications of diagnostic criteria that are based mainly on clinical observation have been widely discussed1-3 as well as the differential diagnosis among the various disorders included in the autism spectrum4-6.

The application of research results to support therapeutic intervention proposals has lead to studies about these processes and their results711.

In recent years some studies about the use of computer technology with children of the autism spectrum have been published. Some of them describe the use of this technology to assess autistic children performance in specific activities 12-13. Others describe the technology's adaptation to the use as alternative/augmentative or aided communication devices 14-19. All of them, however, describe studies with few subjects (less than 10) what diminishes any possibility of generalization of their results. Besides, although inclusion criteria are not always clear, the need of collaborative participation and frequently of high performances may have played an important role in the positive results that are reported. Brazilian reality, however, do not allow the direct "importation" of this kind of technology because there is the need of adaptations that go far beyond the simple translation. On the other hand, most of the autistic children do not have access to specific digital technology, especially adapted to their needs. It is also important to consider that the utility of this kind of technology and their best adaptation to children with different needs still demand more consistent studies that justify the development of programs and systems adapted to Brazilian children.

The purpose of the present study was to observe the advantages of the use of computer technology with commercial programs that are easily available to patients and therapists.

\section{Hypotheses}

1. The use of digital technology in language therapy with autistic children may contribute to the better use of communication opportunities.

2. Children of the autism spectrum in different developmental levels will make different use the digital resources during language therapy.

Aim

Verify the interference of the use of computer and specific programs during the language therapy of autistic children in their functional communicative profile and social cognitive performance.

\section{Method}

The study was approved by the institution's research ethics committee and the caretakers of all children signed the approved consent form.

Subjects

Subjects were 23 children between 3 and 12 years of age, that were attending weekly language therapy on a specialized service for at least 6 months. All have been diagnosed as within the autism spectrum by psychiatrists and none of them were absent from therapy for more than one week.

Inclusion criteria: caretaker signed the consent form, diagnosis within the autism spectrum, age under 11 years at the study onset and behavior adequate to the use of a personal computer.

Material

To the session with the children:

. 2 desktop computers Pentium 4 with configuration compatible to the use of pedagogic games and CDRom games.

. software: pedagogic programs ans CD-Rom gams with different levels.

To data recording:

. individual observation protocol to each session . digital videocameras .midia(miniDVDs) . protocols of the functional communicative profile and social-cognitive performance20-21.

\section{Procedures}

Each subject was filmed individually prior and after a set of 10 sessions with the use of computers during the regular language therapy sessions. In these assessment sessions the children were filmed while 
playing with their therapists and their choice among different kinds of toys. These samples were used to determine each child's functional communicative profile and social-communicative performance.

\section{Results}

The large individual differences among autistic children justify the use of methodologies where the child is his own control. Therefore the statistical analysis compares the two recorded moments in what refer to the functional communicative profile (number of communicative acts per minute, occupation of the communicative space, communication interactivity and use of communicative means) and social cognitive performance (communicative intent, imitation, tool use and play).

Qualitative aspects

The registered data about individualized observations referring to each session allow a qualitative analysis of the whole process.

The first evident information points out that, although there was a collection of about 20 CD-Roms with child's games and a virtually unlimited number of games and activities in the internet, the children usually choose among a few preferred games and some work programs (word $₫$ and paint-brush ${ }^{\circledR}$ ). It was also interesting to note that only three subjects used more than 1 program or game in each session, regardless of its duration and they did it in only 4 sessions.

Figure 1 shows the number of games used by the patients through the 10 studies sessions.

Another aspect that wasn't influenced by the amount of time during which the computer was used was the descriptions provided by the therapists about the children's behavior during the sessions.

Figure 2 shows the proportion of subjects described by the therapists as presenting progress in different areas throughout the 10 sessions. The area that with more descriptions of progresses in the situations with the use of the computer was attention, where progress was described in $24 \%$ of the situations, followed by the increase in communication's interactivity, described in 19\% of the situations. This kind of activity, however, does not contribute significantly to the lessening in agitation patterns of a significant number of subjects. In only $4.5 \%$ of the 230 sessions the patients were described as "less agitated".

Other rather surprising aspect was the increase in eye contact ( $7.7 \%$ of the situations) and in the number of verbalizations (15.4\%) during a kind of activity that can be conducted in an isolated, noninteractive way.

Also contrary to the expected, there was no situation in which the children had shown the desire to continue to use the computer after the planed time. On the other hand, 3 of the 23 subjects had to be stimulated to use the computer and refused to do so in 14 situations, remaining only observing the therapist playing a game or performing some task.

\section{Quantitative aspects}

The analysis of the Functional communicative profiles prior and after the 10 sessions with the use of computer didn't show significant differences in the means of any of the studied variables. However, the individualized comparison between the two moments, with each subject as his own control has shown areas of progress. Statistical analysis (Anova, T-Student and Spearman) has not identified any significant difference (0.05) to any of the variables, but it is possible to consider the number of subjects and the number of areas with progress. The areas considered as progress indexes were: increase in the number of communicative acts per minute; increase in the proportion of use of more interpersonal communicative acts; increase in the proportion of use of the verbal communicative mean; increase in the proportion of us of the vocal communicative mean and decrease in the proportion of use of the gestural communicative mean, without the decrease in the number of communicative acts.

Figure 3 shows the number of subjects with progress in the Functional Communicative Profile and in the social cognitive performance. It is interesting to note that all patients presented at least one progress index in the Functional communicative Profile.

The statistical analysis of the observed areas of the social cognitive performance in the two moments of data gathering also didn't present significant differences. But it was also possible to observe progress indexes in each of the assessed domains. The analyzed areas of the social-cognitive performance were: gestural communicative intent, vocal communicative intent, gestural imitation, vocal imitation, tool use, combinatory play and symbolic play.

Figure 3 also shows the number of subjects with progress in the social cognitive performance. In this analysis 2 subjects didn't present any progress index in none of the seven observed areas. On the other hand it is interesting to note that most of the subjects 
presented a medium number of areas with progress (between 2 and 4 of the 7 observed areas).
FIGURE 1. Proportion of subjects and number of games used in the 10 sessions set.

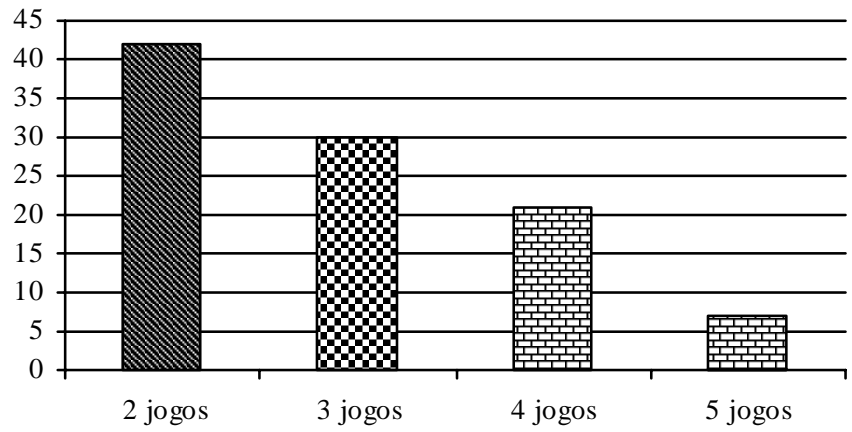

FIGURE 2. Proportion of subjects and areas with changes in behavior/performance.

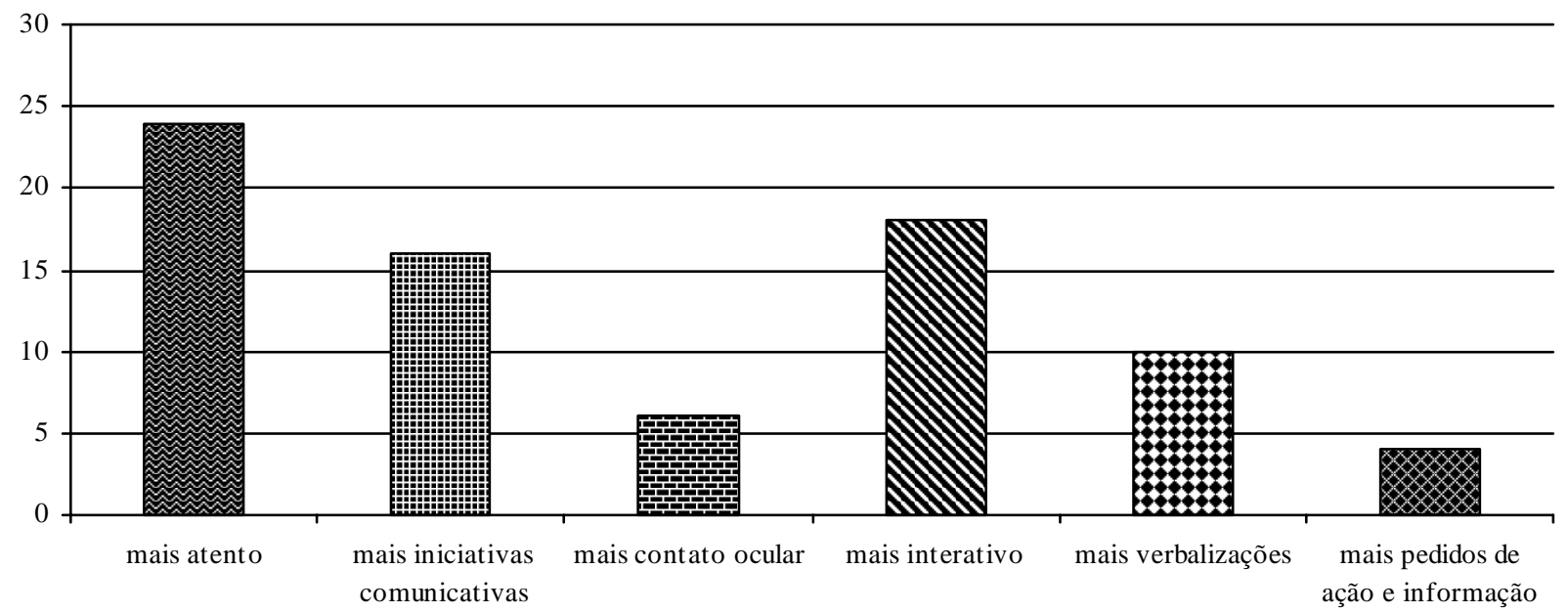

FIGURE 3. Number of subjects and number of areas with progress in the Functional Communicative Profile and in the social-cognitive performance.

número de sujeitos

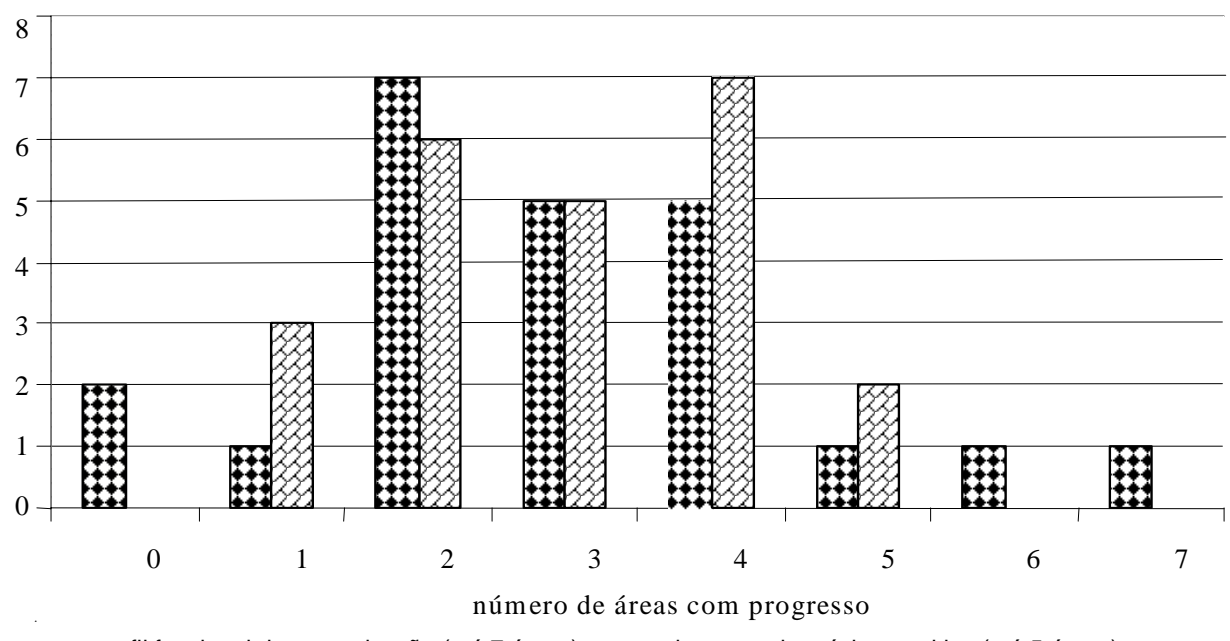

perfil funcional da comunicação (até 7 áreas) $\square$ desempenho sócio-cognitivo (até 5 áreas) 


\section{Discussion}

The qualitative results reinforce the importance of the therapist's role and the established interactive process. The observed evolution in aspects such as increase in the number of verbalizations, of interactivity, of communicative initiatives and eye contact undoubtedly should not be considered as the outcome only of the computer use.

This evolution must be observed as the result of an interactive process in which the computer played different roles according to each interaction: mediation, focus of interest, proposal of challenging situations, competition and collaboration. The therapist's attitudes were also fundamental, acting as a positive interlocutor7-11,20.

The different responses to the to the intervention period in what refer to the Functional Communicative Profile and to the social cognitive performance may be regarded in respect to the kind of activity that used the computer as a mediator to the language therapy20-25. Although this kind of resource favor the virtual performance of different activities and tasks, the real experiencing situation do not occur and it may be significant to the determination of changes in the social cognitive performance26-28. Other studies have already indicated that in some situations the progress in some areas is faster then in other29-30.

\section{References}

1. Klin A, Lang J, Cicchetti DV, Volkmar FR. Brief Report: Interrater Reliability of Clinical Diagnosis and DSM-IV Criteria for Autistic Disorder: Results of the DSM-IV Autism Field Trial. J autism dev disord. 2000;30(2):163-7.

2. Klin A. Asperger syndrome: an update. Rev Bras Psiquiatr. 2003;25(2):103-9.

3. Filipek PA, Steinberg-Epstein R, Book TM. Intervention for Autism Spectrum Disorders. Neuro RX. 2006;3:207-16.

4. Losh M, Capps L. Narrative ability in high-functioning children with autism or Asperger's syndrome. J autism dev disord. 2003;33(3):239-51.

5. Howlin P. Outcome in high functioning adults with autism with and without early language delays: Implications for the differentiation between autism and Asperger syndrome. J autism dev disord. 2003;33(1):3-13.

6. Paul R, Miles S, Cicchetti D, Sparrow S, Klin A, Volkmar F, Cofflin M, Booker S. Adaptative behavior in autism and pervasive developmental disorder-not otherwise specified: Microanalysis of scores on the Vineland adaptative behavior scales. J autism dev disord. 2004;34(2):223-8.

\section{Conclusion}

The first hypothesis proposed to this study stated that: "The use of digital technology in language therapy with autistic children may contribute to the better use of communication opportunities". The results, however, do not provide evidence to confirm or deny it. It was possible to identify progresses qualitatively described by the therapists and qualitatively observable, but without statistical significance. These progresses were observed after a time period that was shorter then the usually used in this kind of comparison, and this seems to be a promising result. However, it wasn't possible to produce more controlled comparisons or associations because the studied group was very heterogeneous, and it restricts the possibility of more consistent conclusions.

The second hypothesis stated that "children of the autism spectrum in different developmental levels will make different use the digital resources during language therapy". It also demands further studies to be effectively confirmed. It was clear that the subjects presented different responses to the use of computer results during the language therapy, but it was not possible to determine if these differences were due to the different uses of the computer, to the development characteristics of each child or to the association of both factors.

The positive results justify the continuity of this kind of study.

7. Fernandes FDM. Sistematização de dados referentes à atualização fonoaudiológica em hospital-dia infantil - o perfil comunicativo como indicador de desempenho. ProFono. 1999a;11(1):1-9.

8. Fernandes FDM, Galinari HDTS. Oficina de linguagem em hospita-dia infantil - primeiros relatos. Pro-Fono. 1999; 11(2):85-91.

9. Fernandes FDM. Um estudo longitudinal da oficina de linguagem como proposta de intervenção para crianças com transtornos do espectro autístico. Rev da soc Brás fonoaudiol. 2003;8(2):64-72.

10. Cardoso C, Fernandes FDM. Terapia de linguagem com crianças do espectro autístico: comparação entre dois modelos de atendimento. Temas desenvolv. 2003; 11(66):34-8

11. Fernandes FDM. Resultados de terapia fonoaudiológica com adolescentes com diagnóstico inserido no espectro autístico. Pró-Fono. 2005;17(1):67-76. 
12. Beaumont RB, Sofronoff K. A new computerized advanced theory of mind measure for children with Asperger syndrome: the Atomic. J autism dev disord. 2008;38(2): 249-60.

13. Kaland N, Smith L, Mortensen EL. Brief roport: cognitive flexibility and focused attention in children and adolescents with Asperger syndrome or high-functioning autism as measured on the computerized versions of the Wisconsin Card Sorting Test. J autism dev disord. 2008; 38(7):1161-5.

14. Bellon-Harn ML, Harn WE. Scaffolding strategies during repeated storybook reading. Focus autism other dev disabil. 2008;23(2):112-24.

15. Herrera G, Alcantud F, Jordan R, Blanquer A, Labajo G, de Pablo C. Developmen of symbolic play through the use of virtual reality tools in children with autistic spectrum disorders. Autism. 2008;12(2):143-57.

16. Shane HC, Albert PD. Electronic screen media for persons with autism spectrum disorders: results of a survey. J autism dev disord. 2008;38(8):1499-508.

17. Franco JH, Lang RL, O'Reilly MF, Chan JM, Sigafoos J, Rispoli M. Functional analysis and treatment of inappropriate vocalizations using a speech-generating device for a child with autism. Focus autism other dev. disabil. 2009;24(3):146-55.

18. Mechilng LC, Gast DL, Seid NH. Using a personal digital assistant to increase independent task completion by students with autism spectrum disorder. J autism dev disord. 2009,39(8):1420-34.

19. Thunberg G, Sandberg AD, Ahlsén E. Speech-generating device used at home by children with autism spectrum disorders. Focus autism other dev. disabil. 2009; 24(2):104-14.

20. Fernandes FDM. Perfil comunicativo, desempenho sócio-cognitivo, vocabulário e metarepresentação em crianças com transtornos do espectro autístico. Pró-Fono. 2003;15(3):267-78.
21. Fernandes FDM, Maeda FR. Investigação de aspectos funcionais da comunicação de crianças autistas - comparação de dois diferentes critérios. J bras fonoaudiol. 2000;1(5):722.

22. Befi-Lopes DM, Araújo K, Fernandes FDM, Gerbelli AE. Comparação de desempenho de crianças autistas em teste de vocabulário: uso de figuras e miniaturas. Rev soc bras fonoaudiol. 2004;9(1):19-24.

23. Cardoso C, Fernandes FDM. A comunicação de crianças do espectro autístico em atividades em grupo. Pró-Fono. 2004;16(1):67-74.

24. Fernandes FDM, Molini-Avejonas DR, Sousa-Morato PF. Perfil funcional da comunicação nos distúrbios do espectro autístico. Rev CEFAC. 2006;8(1):20-6.

25. Miilher LP, Fernandes FDM. Análise das funções comunicativas expressas por terapeutas e pacientes do espectro autístico. Pró-Fono. 2006;18(3):239-48.

26. Sigafoos J, Drasgow E, Halle JW, O'Reilly M, SeelyYork S, Edrisinha C, Andrews A. Teaching VOCA use as a communicative repair strategy. J autism dev disord. 2004; 34(4):411-422.

27. Jarrold C, Brock J. To match or not to match? Methodological issued in autism-related research. J autism dev disord. 2004;34(1):81-6.

28. Bernard-Opitz V, Ing S, Kong TY. Comparison of behavioural and natural play interventions for young children with autism. Autism. 2004;8(3):319-32.

29. Wetherby A, Prizant B. Introduction to autism spectrum disorders. In: Wetherby AM, Prizant BM, editores Autism Spectrum Disorders - A transactional developmental perspective. Baltimore: Paul Brooks. 2001. p.1-7.

30. Lord C, Risi S. Diagnosis of autism spectrum disorders in young children. In: Wetherby AM, Prizant BM, editores Autism Spectrum Disorders - A Transactional Developmental Perspective. Baltimore: Paul Brooks. 2001; p.11-30. 